$12^{\text {th }}$ International Conference on Structural Analysis of Historical Constructions

SAHC 2020

P. Roca, L. Pelà and C. Molins (Eds.)

\title{
STANDARD GRAVITY AND WIND LOAD ANALYSIS ON 103 YEARS OLD UNREINFORCED MASONRY BUILDING
}

\author{
A. KUMAR ${ }^{1 *}$, AND K. PALLAV ${ }^{2}$ \\ ${ }^{1}$ Research Scholar Civil Engineering Department, Motilal Nehru National Institute of Technology \\ Allahabad-211004, Uttar Pradesh, India \\ email: ambar006@gmail.com \\ ${ }^{2}$ Senior Lecturer, Department of Civil Engineering and Surveying, Cape Peninsula University of \\ Technology, Bellville, Cape Town, 7530, South Africa \\ email: kumarp@cput.ac.za
}

Keywords: Ancient structure, masonry building, In-situ survey, Cracks, Finite element modelling, Static analysis

\begin{abstract}
.
Finite element modelling and analysis has been performed on 103-years old unreinforced masonry Senate hall building (SHB), Allahabad University, India. It is an Indo-Saracenic style of architecture which was built in 1915. An in-situ survey is conducted to know the present condition of the SHB. The major and minor cracks are visible, and construction material has deteriorated at various part of the SHB. The old documents, reports, on-site measurement, and photographs are used to gather the historical data and prepared the accurate model of the SHB on Ansys workbench (ANSYS 14.0) tool. Macro and homogenisation approach has used in the modelling of the SHB. The standard gravity and wind load analysis is performed with a fixed boundary condition on its based of SHB. In gravity analysis, maximum stress (5.69MPa) has been observed at the connections of the ground floor and maximum deformation (7.8mm) on the crown of the arch of the first-floor. The maximum stress and deformation 14.286MPa and $12.491 \mathrm{~mm}$ have been observed under live load analysis. Further, the maximum stress and deformation obtained under wind load analysis are $4.10 \mathrm{MPa}$ and $8.07 \mathrm{~mm}$, respectively. The finite element simulation and visual inspection of the SHB are in good agreement with the present condition of the structure.
\end{abstract}

\section{INTRODUCTION}

The Allahabad is one of the very famous and holy cities of Uttar Pradesh, India [1]. The city is located on the confluence of three holy rivers Ganga, Yamuna, and invisible Saraswati which is also known as SANGAM. The unwritten record of history has preserved in buildings like temples, churches, fortresses, mosques, sanctuaries, and cities built of brick and stone. Early efforts to build permanent shelter were limited to the materials. These materials afforded an only primitive opportunity for protection, security, and defence of the shelter. But the stone and brick were used in many architectural remains to date as far back as the ancient walls of 8000 B.C. The study of old historical structures is a very challenging and challenging task due to unknown history, plans, construction techniques, materials, renovation/retrofitting in the past. The engineering study on the old structures is very limited in context to Indian scenario [2-4]. 
The Senate Hall Building (SHB) is an excellent example of Mughal and British techniques like as architectural style, construction techniques and structural elements. Allahabad University is established on $23^{\text {rd }}$ September 1887 , and it is the fourth oldest university of India after Calcutta, Bombay and Madras universities. The university building was designed by William Emerson, who has also designed Victoria Memorial in Calcutta and Crawford Market in Mumbai, in a combination of Indo-Saracenic, Egyptian and Gothic styles. Sir Swinton Jacob designed the building in 1909, and after one the year 1910 construction has been permitted. The foundation of the building was laid on $17^{\text {th }}$ January 1910 by Chancellor Sir John Havett. The construction of the building was started in 1910, and they were finished in 1915. The SHB is an excellent example of the Indo-Saracenic style of architecture, as shown in Fig. 1. In SHB, the mixture of both as detailing and craftsmanship of yellow sandstone presents a wonderful view.

The two-storey building is built upon $1.07 \mathrm{~m}$ thick plinth level with a load-bearing wall of cellular wall arrangement. The building supports large halls, wide verandah, naves, and jack arch roof. The entire SHB has been built up to second-floor level, and only towers are built up to higher leveis. The SHB is symmetrical in the plan at the ground and first-floor level. More than one hundred respected officers and staffs are working in this building. The building is composed of thick walls, arches, towers, columns, vaults, and domes. The three large halls are built on the ground floor level viz., Meeting hall (ME), Examination Hall (EH) and central hall (CH). The

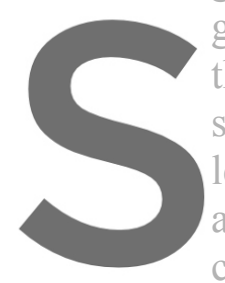
geometrical dimensions the CH. CH is the big sixteen windows are siture level. The SHB is used activities. Figure 1 show
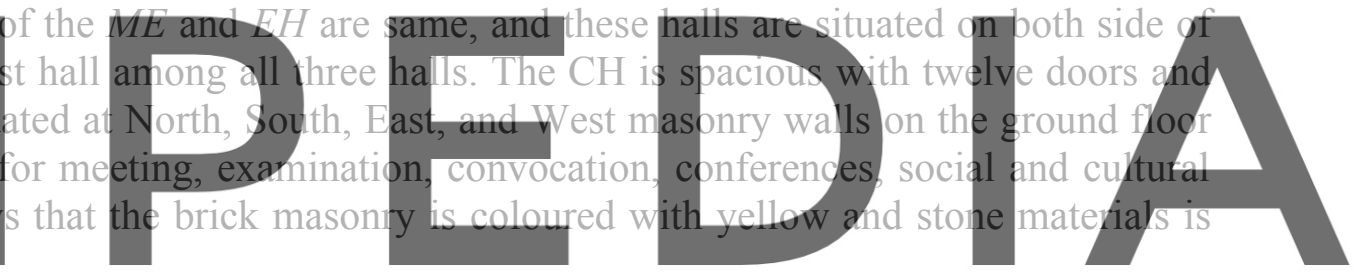

Register for free at https//www.scipedia.com to download the version without the watermark

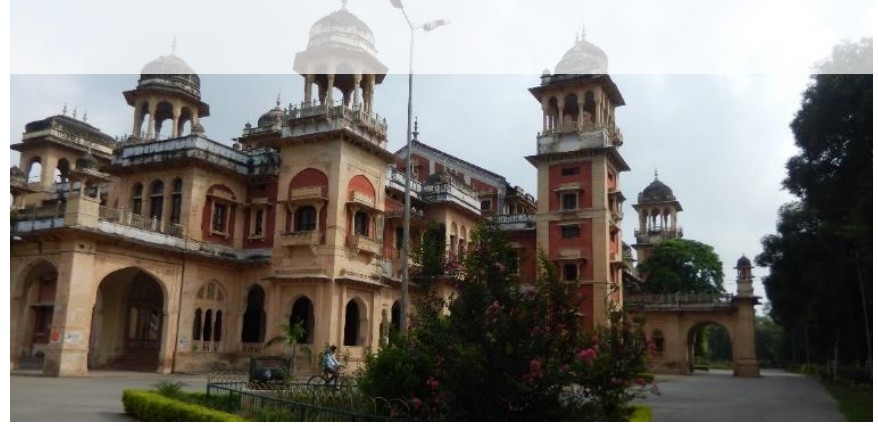

Figure 1: Senate Hall Building, Allahabad university

\section{GEOMETRICAL PLAN}

The engineer-in-charge of the university has provided all the details on the geometrical plan and its past repair and renovation background of the SHB. The geometrical model is prepared with the assistance of the old documentation, visual inspection and photographs of the building. The geometrical dimensions of the SHB are measured from Disto meter, and tape. Figure 2 shows the drawn plan of SHB with all the dimensions. 
A. Kumar and K. Pallav

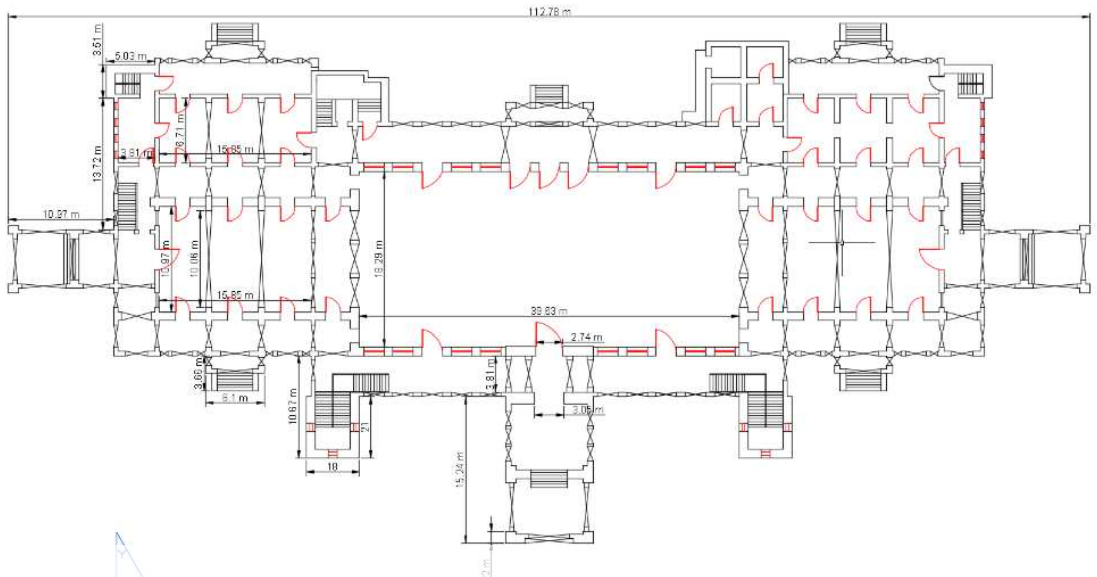

Figure 2: Geometrical plan of the SHB

\section{DAMAGES OF THE SHB}

The SHB has undergone two great earthquakes such as the Bihar-Nepal earthquake 1934 and Nepal earthquake 2015. The reconnaissance survey and visual inspection of the SHB were started on $17^{\text {th }}$ August 2015, and this was the year of devastating $25^{\text {th }}$ April 2015 Nepal earthquake. The major and minor cracks are visible on the ground floor and the seeond floor of the building, as shown in Fig. 3 to Fig 5. The ninor cradks (approx. $1 \mathrm{~mm}-5 \mathrm{~mm}$ ) are visible on the masonry stone facades, crown of the arches, and connections of the ground $5 \mathrm{~mm}-20 \mathrm{~mm}$ ) are visible Fig 4 shows the deterior

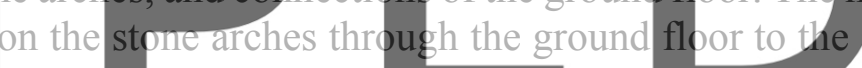
floor portion of the building has mostly damaged due to material deteriorating during the 2015

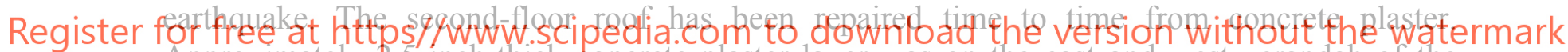
Approximately 2.5-1nch-thick concrete plaster layer was on the east and west verandah of the second-floor level. The meeting halls roof has coated from the tar coal layer to arrest the moisture and seepage in the building. The structural elements of the building such as doors, windows, arches, ventilators and openings, were decorated for the architectural purpose.
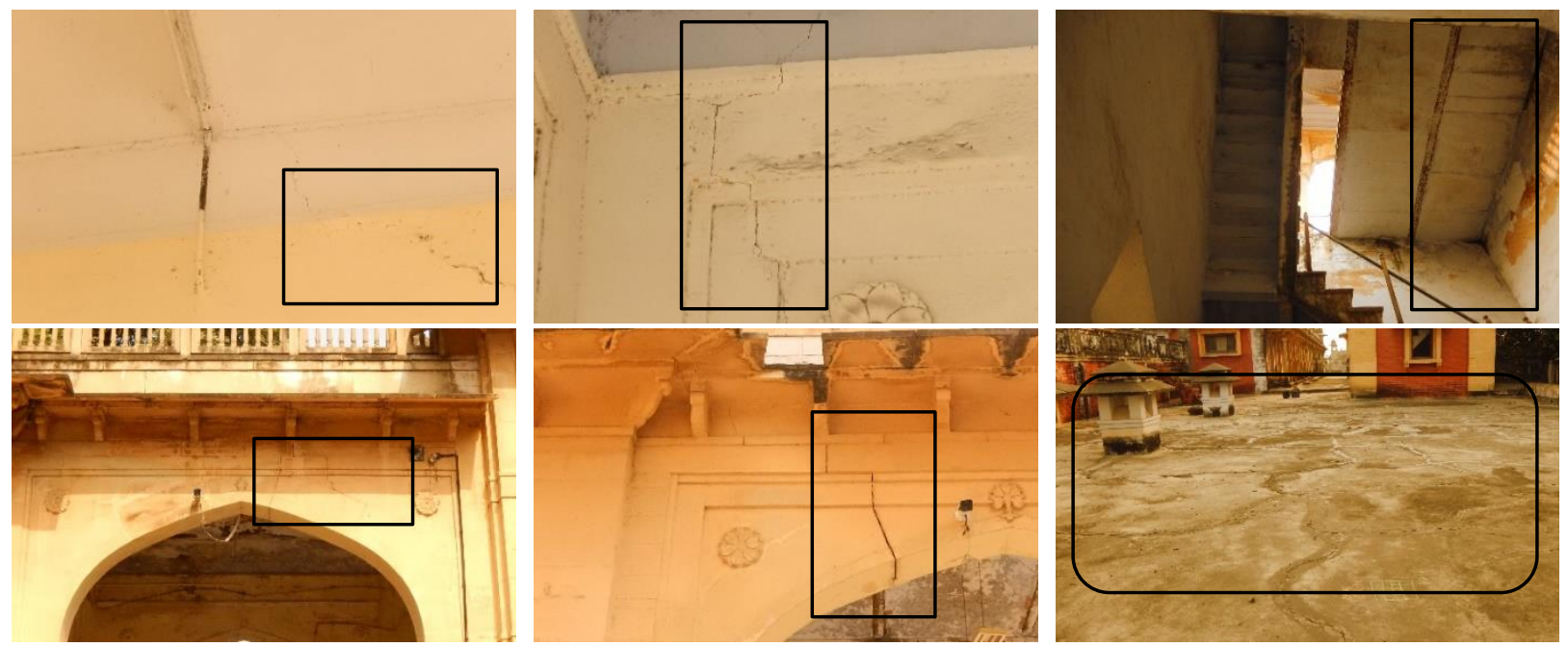

Figure 3: Major cracks $(5 \mathrm{~mm}-15 \mathrm{~mm})$ visible in the building 


\section{A. Kumar and K. Pallav}

Fig. 3 shows the deteriorated portion of the structural element in the rectangular black box. Most of the damages and failures are visible in the towers and boundary wall. The decorating element of the building is a failure in north, south and east entrance porches. The entrance of $\mathrm{MH}$ and $\mathrm{EH}$ of the building is visible major cracks on the ground floor, and first-floor level are closed from brick walls on both side entrance of the portions. Internal side plaster is deteriorated on the stairs and domes due to the effect of seepage, moisture, atmospheric variations. The Central hall bricks wall on the second floor is also deteriorated, and there is a major crack in the octagonal stone columns.
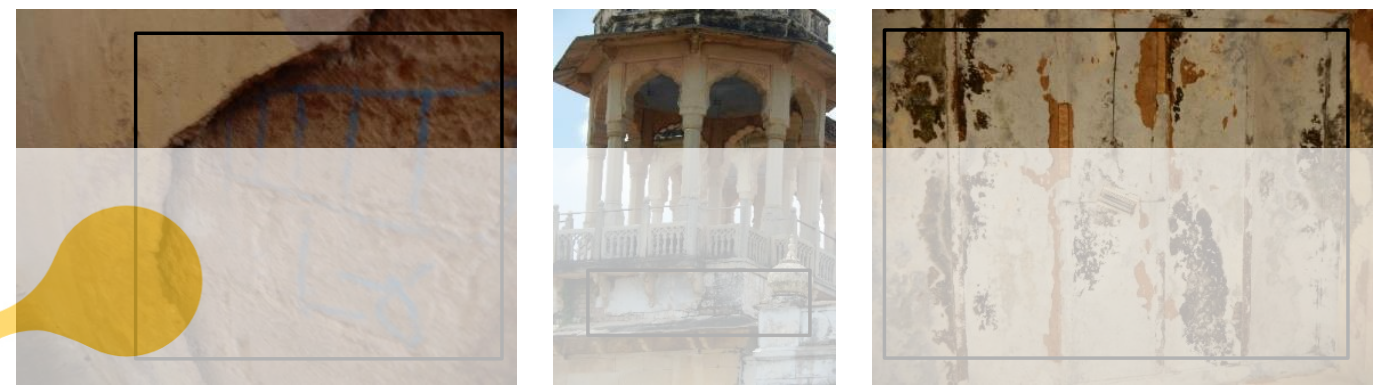

Figure 4: Material deteriorated on different structural components of the SHB

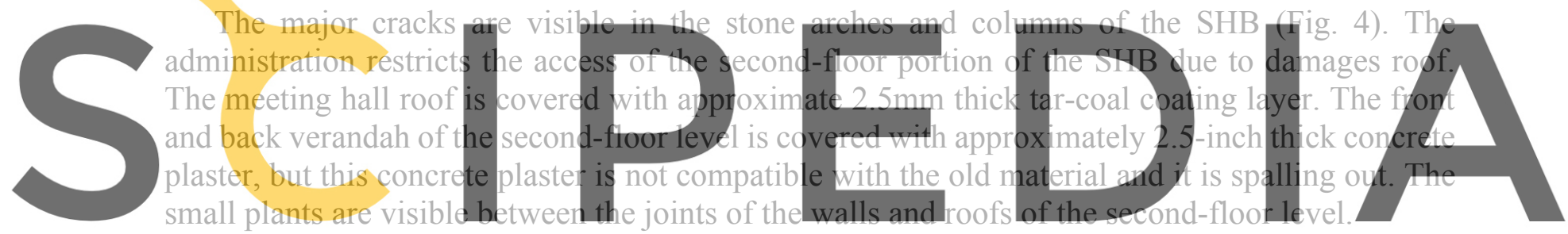

Register for free at https//www.scipedia.com to download the version without the watermark
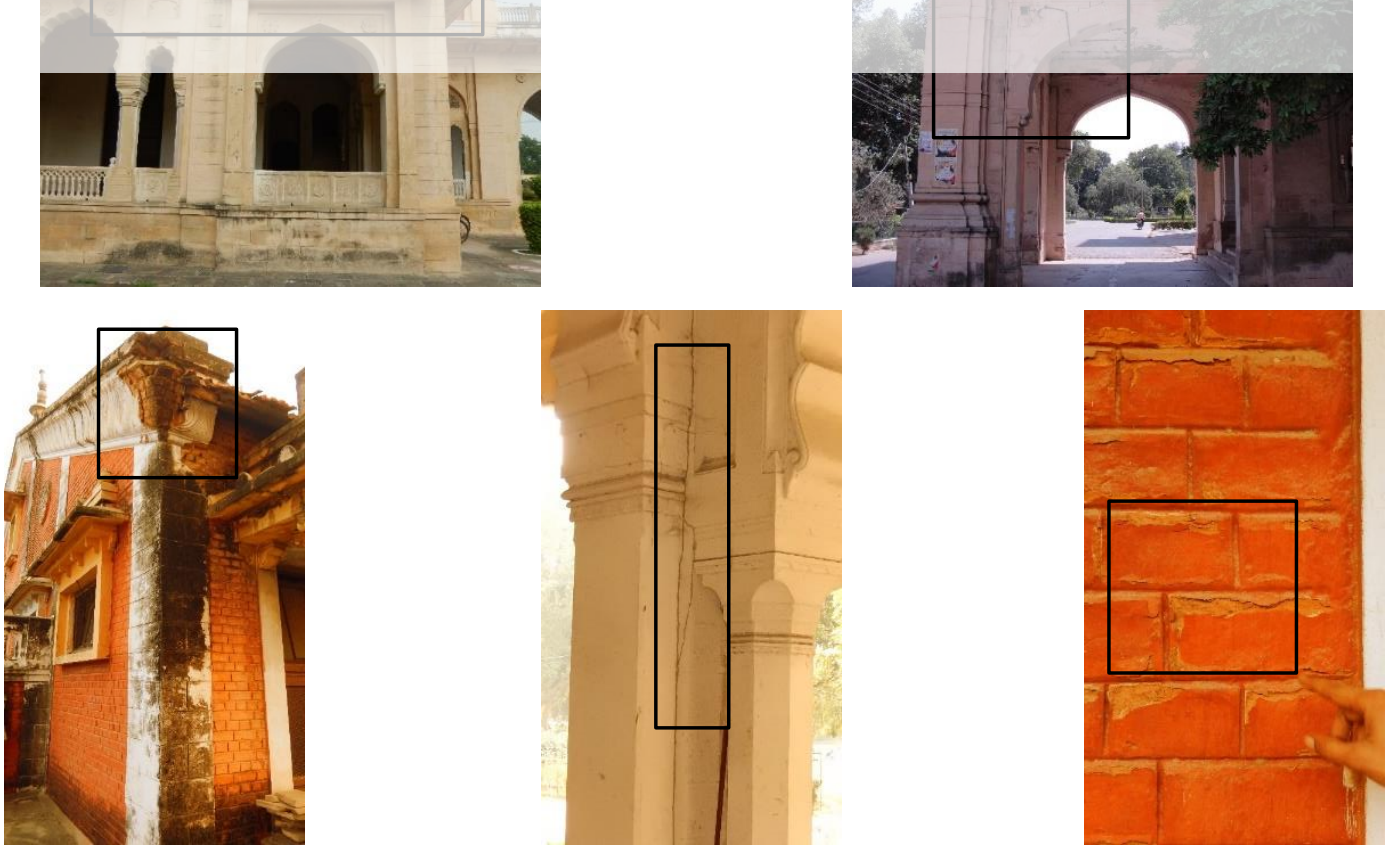

Figure 5: Material deterioration of the SHB 


\section{A. Kumar and K. Pallav}

\section{FINITE ELEMENT MODELLING}

The exact modelling of the old historical monument is difficult tasks due to unknown background knowledge viz., geometry, materials, construction techniques, cracking and damages, renovation, retrofitting of the building. The macro and homogenization techniques is used in preparing the FEM model of the SHB. In the model, only structural elements have been modelled on the Ansys workbench tool (ANSYS 14.0), as shown in Fig. 6. The brick masonry and stone materials have been modelled separately in the FE model of the building. The homogenous condition has been used for masonry and stone materials of the masonry walls and arches elements. The decorating materials have not considered during the modelling and analysis of the SHB building due to microstructural components and material assign difficulties. The 3D finite element model of the SHB is shown in Fig. 6a. The convergence criteria are used for reasonably adjusting the mesh size for entire SHB (Fig. 6b). The mesh size used for masonry wall is $600 \mathrm{~mm}$ for masonry walls, roofs $160 \mathrm{~mm}$, dome elements $120 \mathrm{~mm}$ and for stone arches $100 \mathrm{~mm}$. Altogether, 12,85,779 nodes and 4,73,994 solid elements are created for the modelled SHB. The elements used for solid and surface element in the model are SOLID 186, SOLID 187 and SURF 154 elements. The elements in the model are joined through TARGE 170 and CONTA 174 by using bonded behaviour. SOLID 186 and Solid 187 are 3-D, 20-noded and 10-noded higher order solid element respectively. This element behaviour exhibited quadratic displacement of each node.

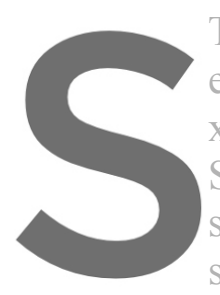
The irregular mesh mod element. Both elements $\mathrm{x}, \mathrm{y}$, and $\mathrm{z}$ directions SOLID 187) have stress strain capabilities. The such as incompressible
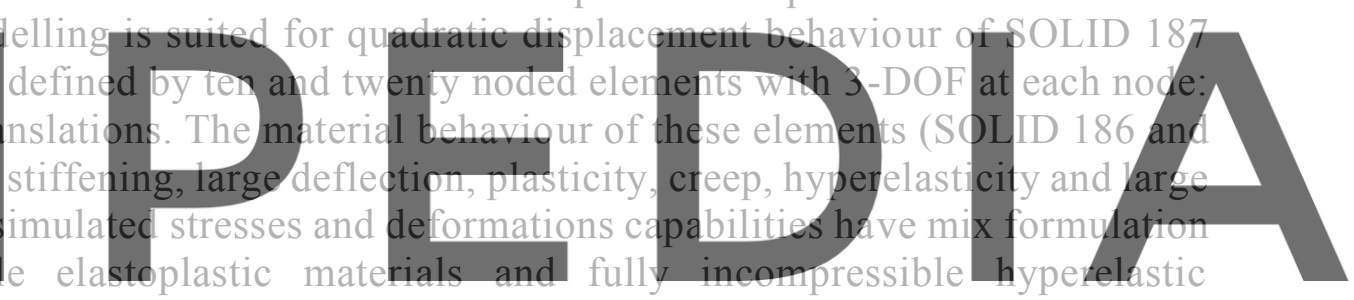

materials. The SURF154 is used in a surface element in the building model for accurate effect

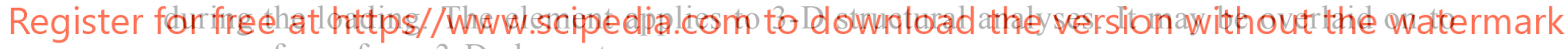
an area face of any 3-D element.
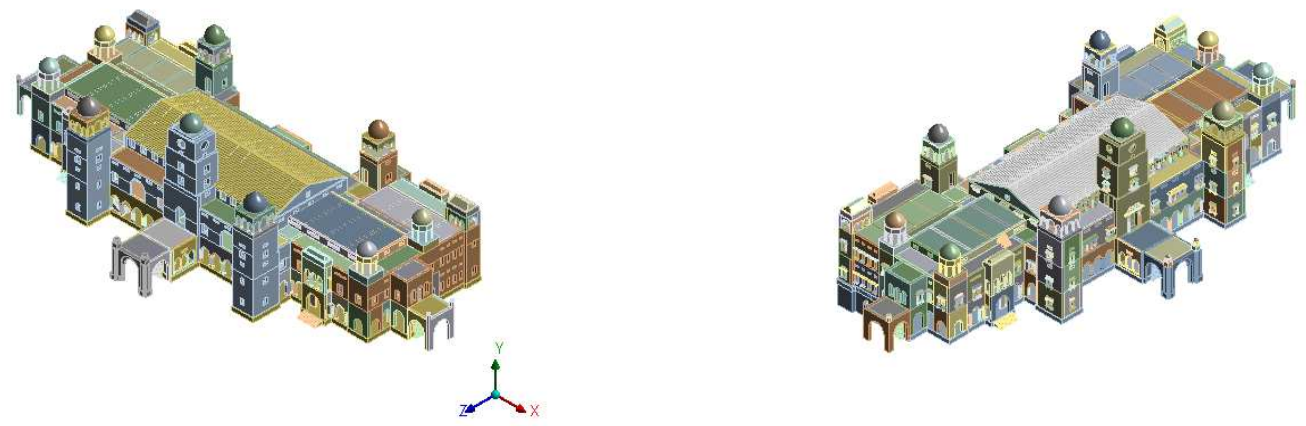

(a) 3D finite element modelling of the SHB 
A. Kumar and K. Pallav
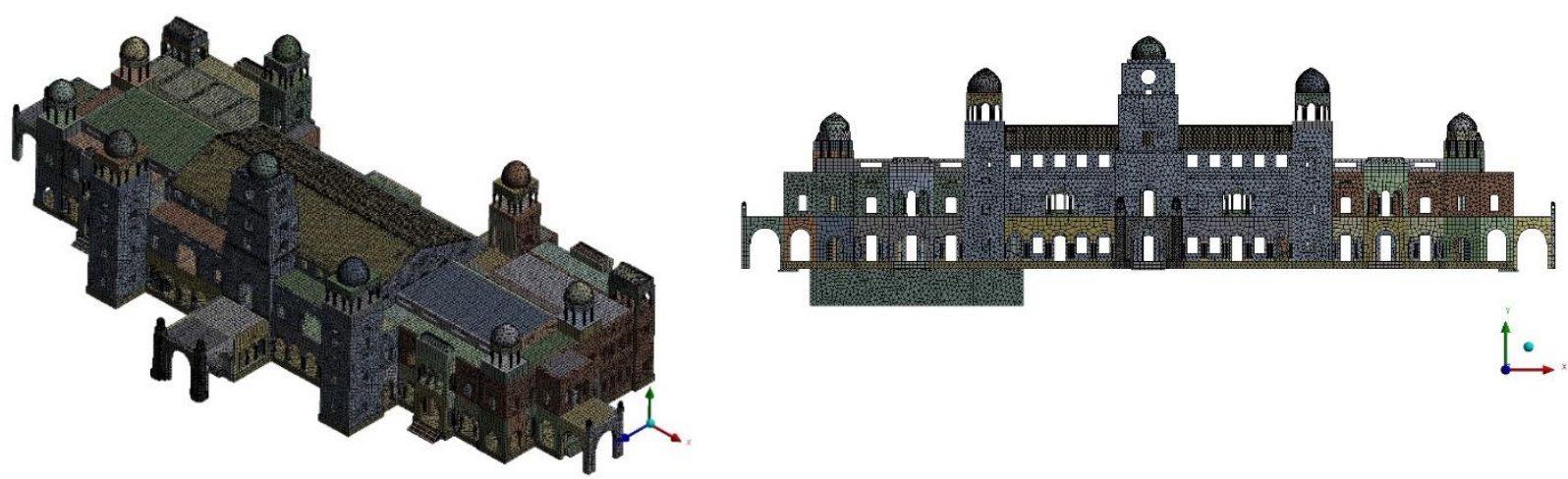

(b) Meshed model of entire SHB

Figure 6: Finite element modelling of the SHB

\section{ANALYSIS}

The analysis of old historical structures is a challenging task due to unknown material properties, connections, hidden cracks, damages, etc. In the present model, cracks and damages are not being modelled. The evaluation of mechanical properties of ancient structures is challenging, and only non-destructive testing is one source for evaluating the mechanical properties. The building has been analyzed for three different laading conditions as given by the Bureau of Indian standard viz gravity [18], live load [19]; and wincload [20]. The ma of the first and second floor of the building are closed due to damages of the structur The live load has been considered for accessible and non-accessible portions on the bu wind pressure has been calculated from the Indian code and distributed along with th the building (Table 1) The prominent wind direction for the towers is from the sou

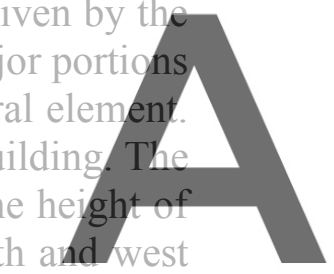

direction. The analysis of the SHB has been considered for a fixed base. Table 2 shows the material

Register firplfrees a

Velocity Test). The analyses show the maximum von-Mises stress and deformation of the SHB building. The analyses show the observed weak connections, maximum stresses positions, to suggest for strengthening and retrofitting of structural elements and joints.

Table 1: Variation of the wind pressure of the SHB

\begin{tabular}{cccc}
\hline Height (m) & $\begin{array}{c}\text { Terrain Category 3 class } \\
\text { B }\end{array}$ & $\begin{array}{c}\text { Design wind speed } \\
(\mathbf{m} / \mathbf{s})\end{array}$ & $\begin{array}{c}\text { Design wind pressure } \\
\left(\mathbf{N} / \mathbf{m}^{\mathbf{2}}\right)\end{array}$ \\
\hline $10 \mathrm{~m}$ & 0.88 & 44.26 & 391.71 \\
\hline $15 \mathrm{~m}$ & 0.94 & 47.27 & 446.94 \\
\hline $20 \mathrm{~m}$ & 0.98 & 49.28 & 485.78 \\
\hline $30 \mathrm{~m}$ & 1.03 & 57.80 & 536.62 \\
\hline $50 \mathrm{~m}$ & 1.09 & 54.52 & 600.96 \\
\hline
\end{tabular}

Table 2: Mechanical properties of the SHB

\begin{tabular}{lccc}
\hline Floor & Density $\boldsymbol{\rho}\left(\mathbf{k g} / \mathbf{m}^{\mathbf{3}}\right)$ & Young's Modulus E $(\mathbf{M P a})$ & Poisson's ratio $(\boldsymbol{\mu})$ \\
\hline Brick masonry & 2100 & 2400 & 0.2 \\
\hline Stone & 2400 & 6470 & 0.2 \\
\hline
\end{tabular}




\section{A. Kumar and K. Pallav}

\section{RESULTS AND DISCUSSION}

Fig. 7 shows the stress and deformation response to gravity load analysis. The maximum stress of $5.69 \mathrm{MPa}$ is observed on the connection between the back verandah wall and the ground floor of the stair tower. The stress is negligible on the ground floor masonry walls, and this may be due to its thickness that provides a large area to transfer the building load. The brick masonry walls of the central hall and side halls on the ground floor perform better than the stone masonry walls. The observed stress on the internal portion of stone arches, columns and facades of the meeting and examination hall are in the range of $1.62 \mathrm{MPa}$ to $2.03 \mathrm{MPa}$ and it is shown in Fig. 7a. The major stress has affected the connection between wall to wall, wall to the roof, roof to the tower of the building from the ground floor to the second floor. The maximum deformation of $7.80 \mathrm{~mm}$ is observed at the second-floor of south facade wall of the central hall. The directional deformation of the entire building has observed negligible. The longitudinal and transverse directional deformation of the building is observed approximately similar to $1.4 \mathrm{~mm}$, but vertical directional deformation of $0.03 \mathrm{~mm}$ is observed at first-floor wall of the meeting hall. The overall deformation response of the SHB is shown in Fig. 7b. The deformation of the clock tower and side stair tower is observed in the range of $3.9 \mathrm{~mm}$ to $4.45 \mathrm{~mm}$ from the third floor to sixth-floor level.

Fig. 8 shows the stress and deformation response of the SHB due to live load. The maximum stress $14.28 \mathrm{MPa}$ has been observed on the openings of the window and connections between wall and roof joint of the second-floor level. The in-s tu survey of the SHB shows the major cracks ard damages on the stone columns, arches and walls on the position on stone arches of the meeting hall and examination hall are ob 6.1MPa, respectively. The maximum deformation of $12.49 \mathrm{~min}$ second-floor and at the rof of the central hall in the building. I-section; the access of these portions is restricted.

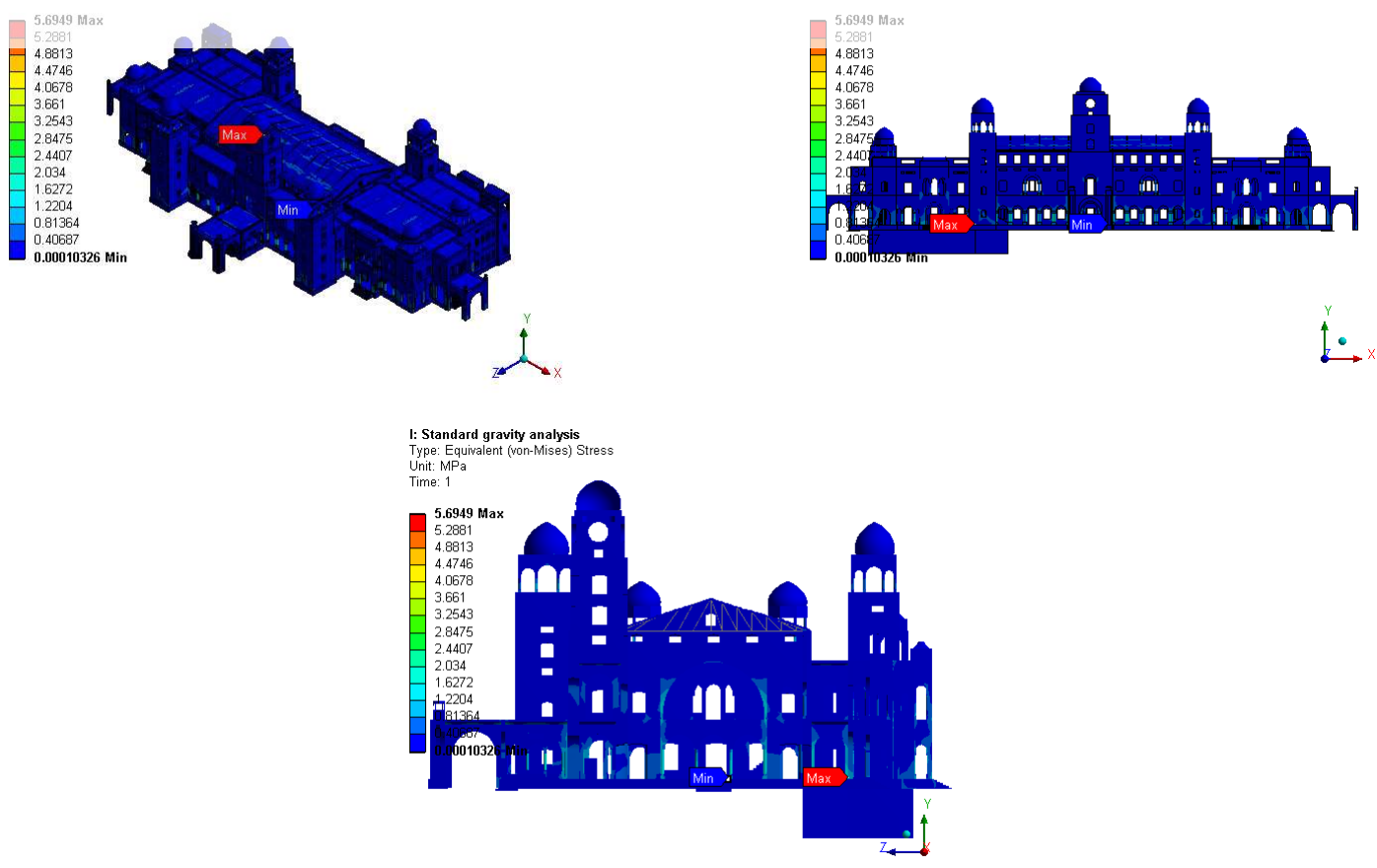


A. Kumar and K. Pallav

(a) von Mises stress behaviour of the SH building
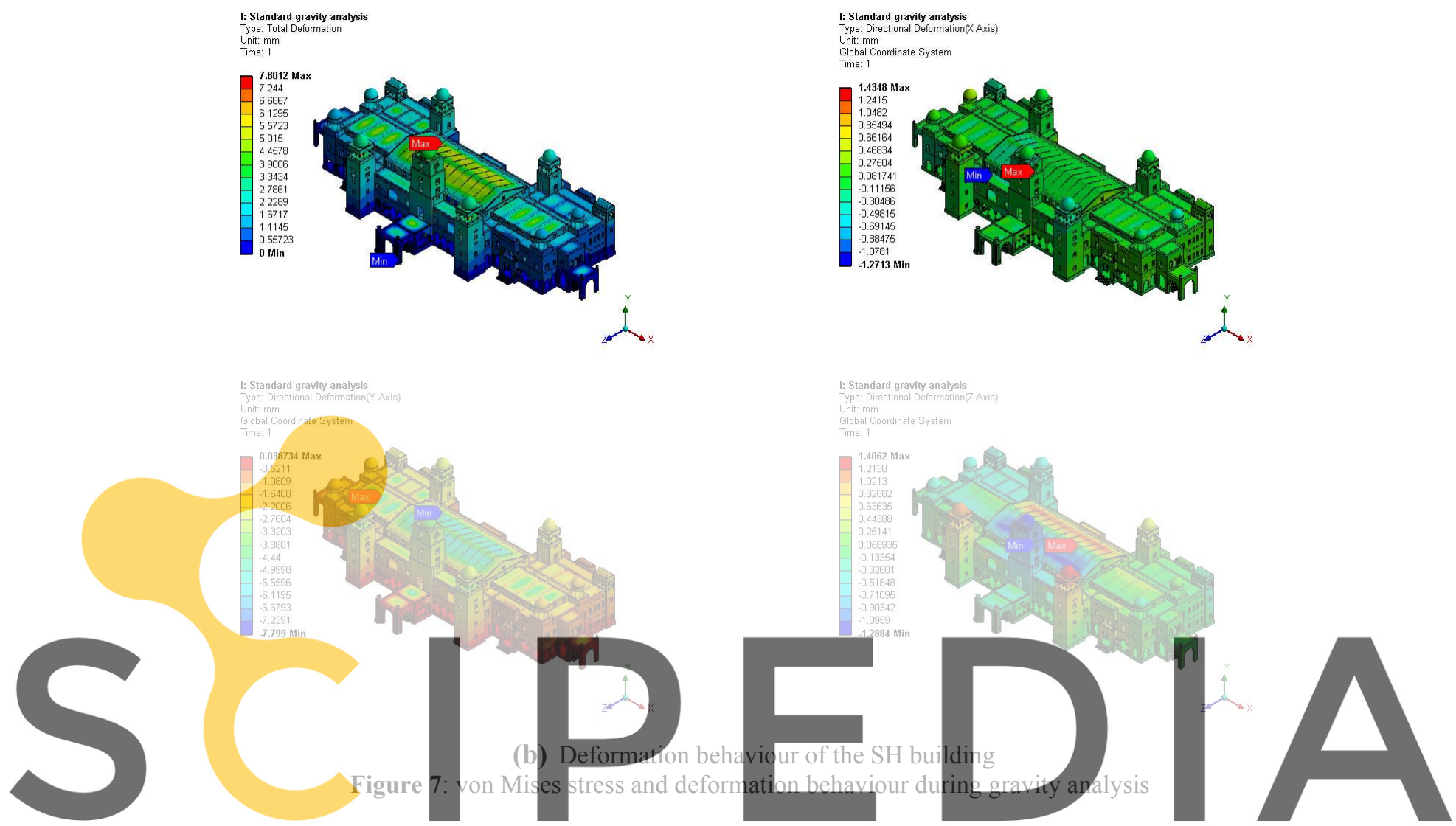

The longitudinal and transverse deformation has been observed on the second floor as $1.51 \mathrm{~mm}$

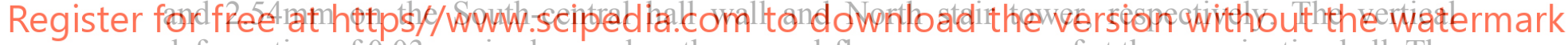
deformation of $0.03 \mathrm{~mm}$ is observed on the second-floor masonry roof at the examination hall. The tower of the SHB building is geometrically stable for gravity and live load. The masonry walls are performing better than arches and roof elements of the building.

Further, to know the stress generated through the lateral load; wind analysis has been performed on the SHB building. The maximum stress of $4.10 \mathrm{MPa}$ is observed on the wall of the ground floor level between the central hall and examination hall verandah. The stress range on the octagonal columns, domes, tile roof, the balcony from $0.87 \mathrm{MPa}$ to $1.17 \mathrm{MPa}$. Front corner tower has observed the stress $1.75 \mathrm{MPa}$ to $2.05 \mathrm{MPa}$ at the ground and first-floor level. The maximum deflection $8.07 \mathrm{~mm}$ is observed on the verandah (backside) of the second-floor. The longitudinal and transverse direction deformation is estimated as $1.30 \mathrm{~mm}$ and $1.33 \mathrm{~mm}$, respectively. The vertical directional deformation $0.04 \mathrm{~mm}$ of the building has observed as negligible at the secondfloor level. 
A. Kumar and K. Pallav
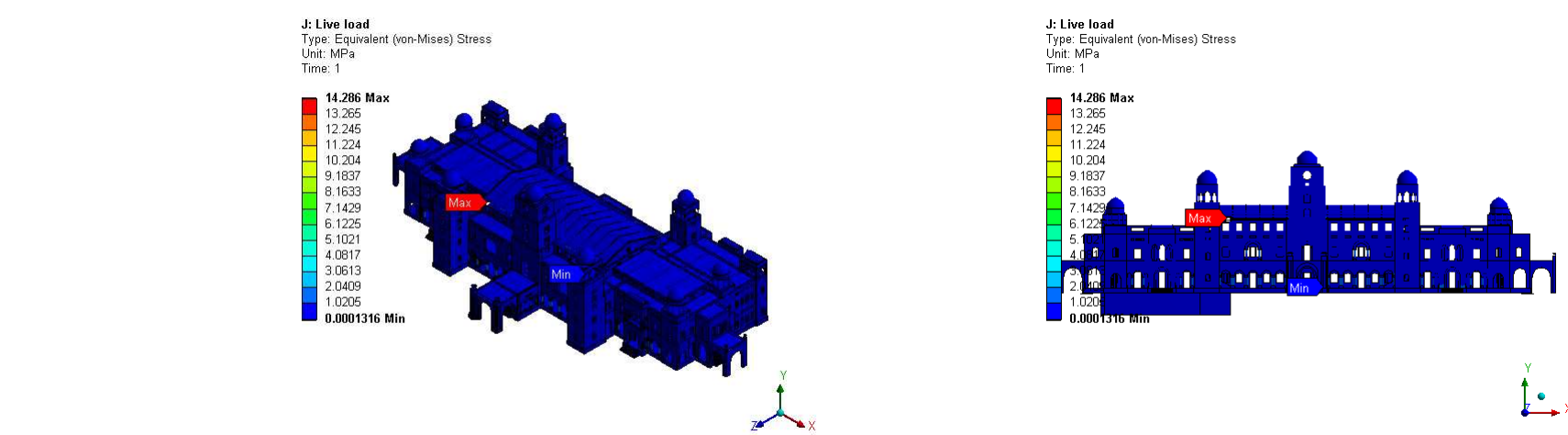

$\stackrel{\gamma}{\stackrel{\gamma}{\longrightarrow} x}$

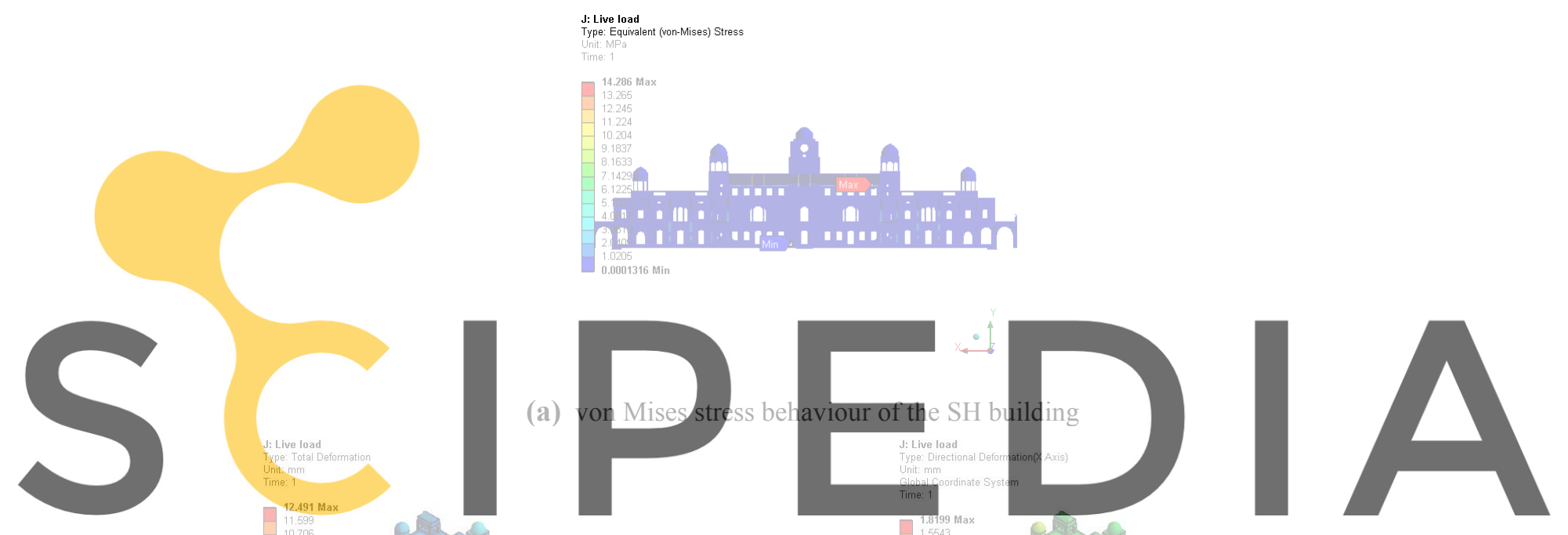

Register for free at https//www.scipedia.com to download the version without the watermark
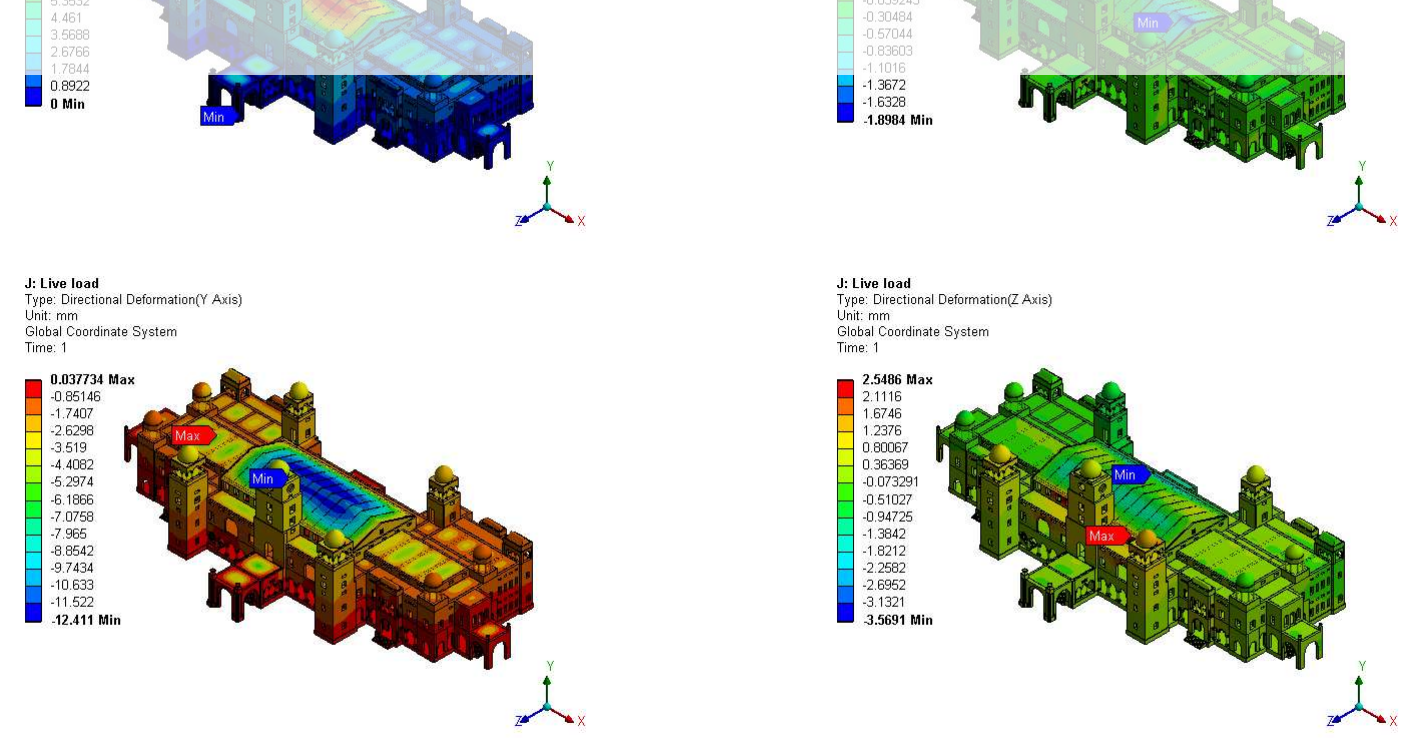

(b) Deformation behaviour of the SH building

Figure 8: von Mises stress and deformation behaviour during live load analysis 
A. Kumar and K. Pallav
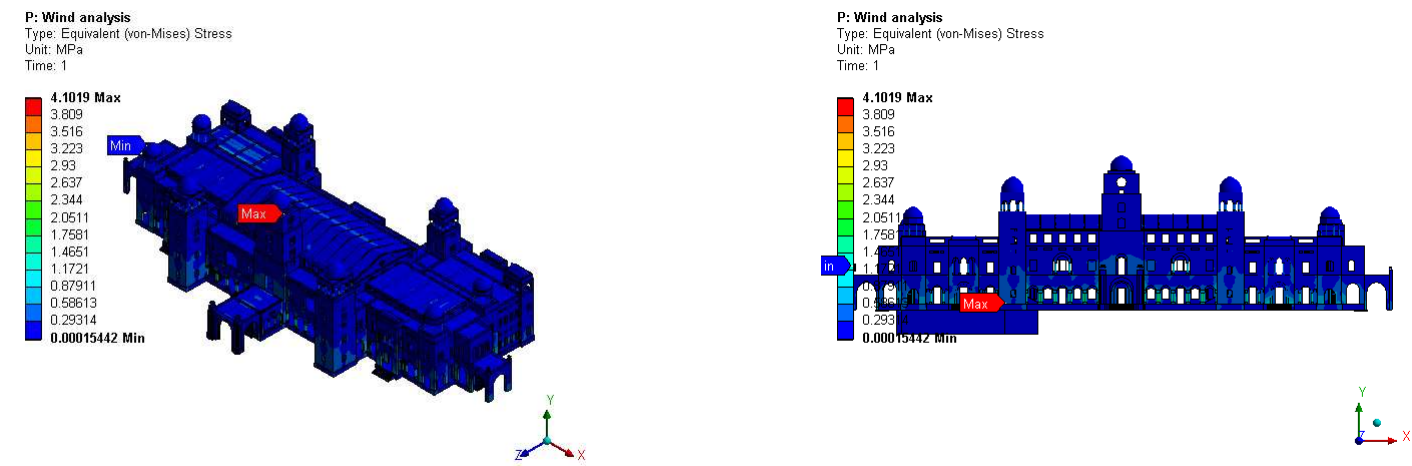

(a) von Mises stress behaviour of the SH building

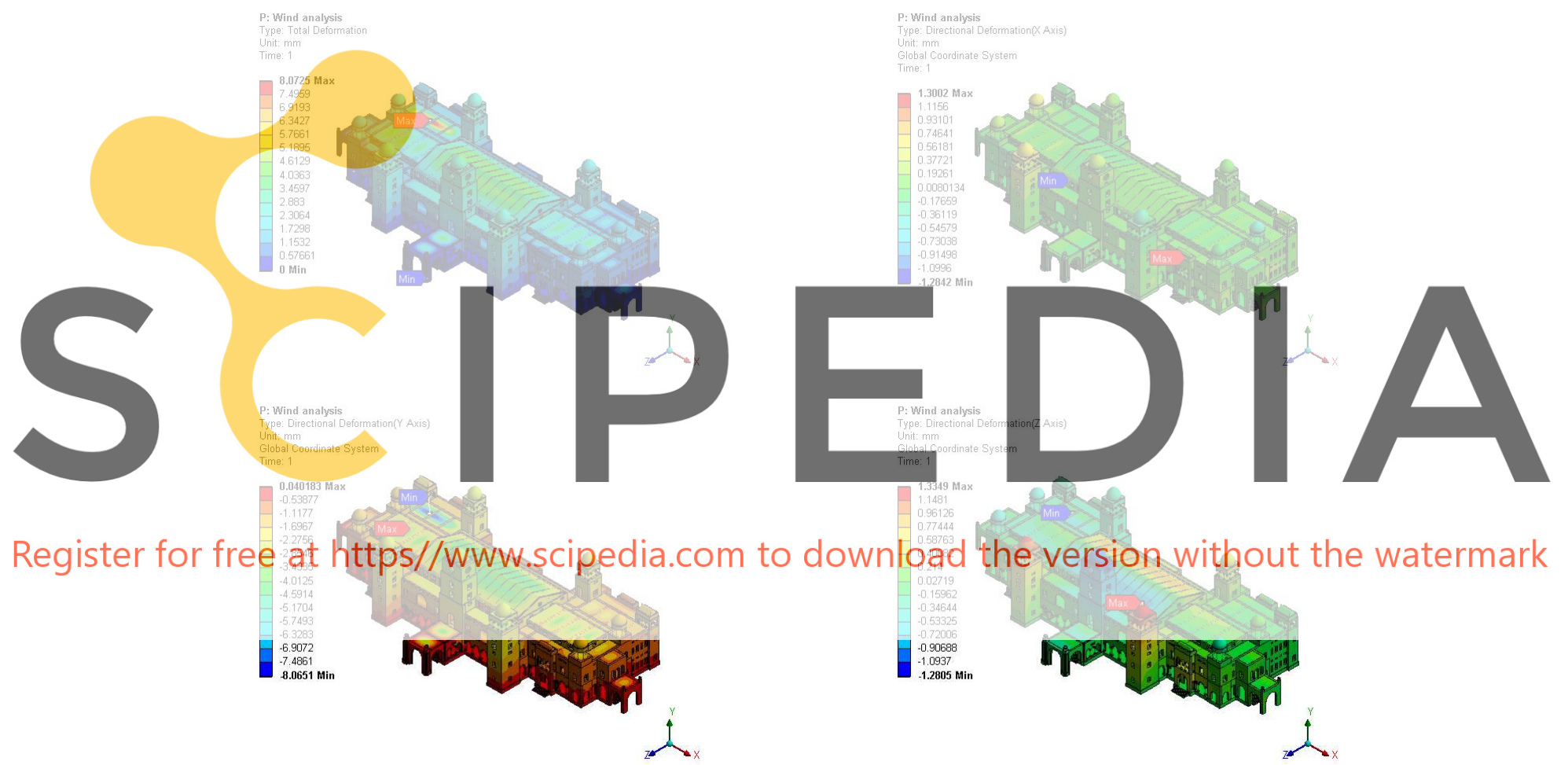

(b) Deformation behaviour of the SH building

Figure 9: von Mises stress and deformation behaviour during wind analysis

\section{CONCLUSION}

The paper has presented a finite element approach for an unreinforced historical building of Allahabad University which is an excellent example of the Indo-Saracenic style of architecture. The in-situ investigation and retrofitting solutions are suggested to conduct computationally expensive instruments (e.g., time history method, kinematic analysis and pushover analysis) with more sophisticated ones (e.g., microelement approach) can offer proper indications in the structure. The study on the senate hall building leads to the following conclusions. The building is massive in its configuration which provides adequate stability to the structure. In a reconnaissance survey, the major cracks and damages are shown on various structural elements and the openings of the building due to previous earthquakes events and weathering effect. The structural configuration of the building is adequate to withstand the vertical and horizontal loads during the gravity and wind 


\section{A. Kumar and K. Pallav}

loads. The entrance porches of the building are more vulnerable on the ground floor level. The analysis suggests that most of the elements of the building need retrofitting and also connections needs to repair between the element. Most of the portion of the building is renovated with new material.

Acknowledgements. The authors would like to thanks Mr Naveen Kumar civil engineer and their staff, who very graciously provided access to the building and gratefully acknowledged for making possible the cooperation between the knowledge about the geometric survey, renovation and retrofitting of the $\mathrm{SHB}$.

\section{REFERENCES}

[1] MISRA, R.N., "Architectural Triveni of Allahabad and Asphyxiation of a Monumental Dream (P.K. Acharya and his Manasara)". https://goo.gl/9VGxvy

[2] Dubey, R.N., Thakkar, S.K., Gupta, A., "Seismic analysis for safety evaluation of Taj Mahal Monuments", Eleventh Would Conference on Earthquake Engineering, ISBN: 0080428223.

[3] Ramos, L.F., Casarin, F., Algeri, C., Lourenco, P.B., Modena, C., (2006), "Investigation Techniques Carried out on the Qutb Minar, New Delhi, India", Structural Analysis of Historical Constructions, New Delhi. https://bit.ly/2WS3jeS

[4] Pena, F., Lourenco, P.B., Mendes, (2008), "Seismic Assessment of the Qutb Minar in Delhi, India", $14^{\text {th }}$ World Conference on Earthquake Engineering October 12-17, Beijing, China. https://bit.ly/2w89IXI

[5] Cakir, F., Uckan, E., Shen, J., Seker, B.S., Akbas, B., (2015), "Seismic damage evaluation of historical structures during Van earthquake, October 23, 2011", Engineering Failure Analysis, 58, 249-266.

[6] Mosoarca, M., and Gioncu, V., (2013), "Failure mechanisms for historical religious buildings in Romanian seismic areas", Journal of Cultural Heritage, 14S, 65-72.

[7] Shakya, M., and Kawan, C.K., (2016), "Reconnaissance based damage survey of buildings in Kathmandu valley: An aftermath of 7.8 Mw, 25 April 2015 Gorkha (Nepal) earthquake", Engineering Failure Analysis, 59, 161-184.

[8] Lirola, J.M., Castaneda, E., Lauret, B., Khayet, M., (2017), “A review on experimental research using scale models for buildings: Application and methodologies", Energy and Buildings, 142, 72-110.

[9] Sassoni, E., Mazzotti, C., Pagliai, G., (2014), "Comparison between experimental methods for evaluating the compressive strength of existing masonry buildings", Construction and Building Materials, 68, 206-219.

[10] Gracia, V.P., Caselles, J.O., Clapes, J., Martinez, G., Osorio, R., (2013), "Non-destructive analysis in cultural heritage buildings: Evaluating the Mallorca cathedral supporting structures", NDT\&E International, 59, 40-47.

[11] Casarin, F., and Modena, C., (2008), "Seismic assessment of complex historical buildings: application to Reggio Emilia cathedral, Italy", International Journal of Architectural Heritage, 2, 304-327.

[12] Brandonisio, G., Mazziotti, A., Lucibello, G., Mele, E., Luca, A.D., (2014), "Seismic behaviour of four Italian masonry buildings: comparison between different modelling", SAHC2014-9 ${ }^{\text {th }}$ International Conference on Structural Analysis of Historical Constructions, Mexico City, Mexico, 14-17 October. 


\section{A. Kumar and K. Pallav}

[13] Kumar, A., and Pallav, K., (2017), "Static and Dynamic analysis of Masonry tower of Allahabad University, India", VIII ECCOMAS Thematic conference on Smart Structures and materials (SMART-2017), $5^{\text {th }}-8^{\text {th }}$ June Madrid, Spain. https://goo.gl/RYpBj1

[14] Kumar, A., Pallav, K., and Singh, D.K., (2017), "Static and dynamic analysis of stone arch of Allahabad University", International Conference on Recent Innovations in Engineering and Technology (ICRIET-2017), $18^{\text {th }}-19^{\text {th }}$ Feb. 2017, Jaipur. [ISBN: 978-93-86291-639] https://bit.ly/2LRm5RD

[15] Kumar, A., and Pallav, K., (2018), "Static and dynamic analysis of unreinforced masonry wall using finite element modeling in senate hall building", The 2018 Structures Congress (Structures18) Songdo Convensia, Incheon, Korea, August 27 - 31, 2018. https://bit.ly/2STF3I5

[16] Valente, M., and Milani, G., (2016), "Non-linear dynamic and static analyses on eight historical masonry towers in the North-East of Italy", Engineering Structures, 114, 241270.

[17] Milani, G., Casolo, S., Naliato, A., Tralli, A., (2012), "Seismic Assessment of a Medieval Masonry Tower in Northern Italy by Limit, Nonlinear Static, and Full Dynamic Analyses", International Journal of Architectural Heritage, 6, 489-524.

[18] IS:875 (Part-1) 1987, Code of practice for design dead loads for building and structures, Bureau of Indian Standards, New Delhi.

[19] IS:875 (Part-2) 1987, Code of practice for design live loads for buildings and structures. (imposed load)", second revision, part-1, Bureau of Indian Standards, New Delhi.

[20] IS:875 (Part-3) 2015, Code of practice for design wind loads for buildings and structures, Bureau of Indian Standards, New Delhi.

[21] Sivaraja, S.S., Thandavamoorthy, T.S., Vijayakumar, S., Aranganathan, S.M., Dasarathy, A.K., (2013), "Preservation of Historical Monumental Structures using Fibre Reinforced Polymer (FRP) - Case Studies", Procedia Engineering, 54, 472-479.

[22] Akcay, C., Bozkurt, T.S., Sayin, B., Yildizlar, B., (2016), "Seismic retrofitting of the historical masonry structures using numerical approach", Construction and Building Materials, 113, 752-763.

[23] Hegazy, S.M., (2015), "Conservation of historical buildings-The Omani-French museum as a case study", Housing and Building National Research Center (HBRC) Journal, 11, 264-274. 